\title{
Biomass allocation in natural regeneration of Fagus sylvatica and Picea abies trees in Italian Alps
}

\author{
Fabio Pastorella1,* and Alessandro Paletto ${ }^{2}$
}

Pastorella, F., Paletto, A. 2014. Biomass allocation in natural regeneration of Fagus sylvatica and Picea abies trees in Italian Alps. - Forestry Studies | Metsanduslikud Uurimused 61, 35-46. ISSN 1406-9954. Journal homepage: http:/ / mi.emu.ee/forestry. studies

\begin{abstract}
Biomass allocation in seedlings and saplings at different stages of growth is important information for studying the response of species to site conditions. The objectives of the paper are: (a) to analyse the relationship between height and biomass in young Norway spruce and European beech trees, (b) to study the influence of the leaf area on ontogenetic growth stages and biomass sequestration capacity on the regeneration of these two species. 96 seedlings $(\mathrm{H}<30 \mathrm{~cm})$ and saplings $(31<\mathrm{H}<130 \mathrm{~cm})$ were collected in different light conditions in a case study in the Alps (Trentino province, Italy). Leaf Area Index and shoot/root ratio were used as indicators of the ecological conditions (e.g. light, soil moisture, nutrient status) able to influence the seedlings and saplings growth. Two non-linear regressions were fitted to analyse the relationship between height and biomass and to develop the aboveground and below-ground allometric equations. Non-linear regressions show that sapling or seedling height is a good predictor of above-ground and below-ground biomass with a $\mathrm{R}_{\mathrm{aj}}^{2}$ above 0.8 for all equations and a $\mathrm{R}_{\mathrm{aj}}$ above 0.9 for above-ground biomass of Norway spruce. The results show that silvicultural practices may influence the regeneration patterns and increase the biomass allocation rate influencing stand density and canopy cover.
\end{abstract}

Key words: Norway spruce, European beech, allometric equation, saplings, seedlings, Leaf Area Index.

Authors' addresses: 1Project Centre "MOUNTFOR", European Forest Institute (EFI), San Michele A/A (TN), 38010, Italy; ${ }^{2}$ Forest Monitoring and Planning Research Unit, Council for Agricultural Research and Economics, Trento, 38123, Italy;

*e-mail: fabio.pastorella@entecra.it

\section{Introduction}

Estimates of the carbon stocks in vegetation biomass are a fundamental information by the United Nations Framework Convention on Climate Change (UNFCCC, 1992) and Kyoto Protocol (UNFCCC, 1997). These political documents recognized that forest ecosystems contribute to mitigate the anthropogenic greenhouse effect (Teobaldelli et al., 2009; Durkaya et al., 2013). The Intergovernmental Panel for Climate Change published the Good Practice Guid- ance (IPCC GPG) in 2000 for reporting carbon stocks in tree above-ground and below-ground biomass in a transparent and verifiable way (Penman et al., 2004).

Biomass and carbon stocks are generally estimated using biomass functions (Cienciala et al., 2005; Ruiz-Peinado et al., 2012), applying the biomass expansion factors (BEFs) (Levy et al., 2004; Skovsgaard \& Nord-Larsen, 2012) or adopting non-destructive methods based on photo imagery (Ter-Mikaelian \& Parker, 2000). The international literature has mainly focused on 
biomass allocation in mature and old trees, while few studies have focused on the above-ground and below-ground biomass in young and very young trees (e.g. Elliott \& Clinton, 1993; Claesson et al., 2001; Pajtík et al., 2011; Blujdea et al., 2012). Generally, allometric equations estimated for large trees are not applicable to young trees. In addition, many of these studies considered shoot growth but not root growth (Canham \& Marks, 1985). Yet seedling and sapling biomass are important variables used to measure the net primary productivity, to estimate the carbon sequestration potential of forest stands, and to evaluate the performance of forest regeneration after different silvicultural treatments (Schmidt et al., 2009; Øyen et al., 2011). Consequently, the estimation of seedling and sapling biomass and the analysis of the relationship between shoot/root (R/S) ratio and site characteristics might help forest managers to promote the growth of desired tree species (DeLucia et al., 1998).

The growth and survival of young trees is influenced by multiple site characteristics such as light, altitude, soil fertility and competition with the surrounding vegetation. In particular, light plays an outstanding role in forests, at least on mesic sites in temperate regions, and it can easily be manipulated by silvicultural treatments (Petrițan et al., 2008).

Leaf Area Index (LAI) can be defined as the amount of foliage area in a canopy per unit ground surface area $\left(\mathrm{m}^{2} \mathrm{~m}^{-2}\right)$ (Watson, 1947) and it is a dynamic parameter that depends on species composition, developmental stage, prevailing site conditions, season of the year and management practices and it expresses the photosynthetic and transpiration surface of plant canopies (Jonckheere et al., 2005). In the literature there are several methods for groundbased estimation of LAI (Liang et al., 2012): direct methods (destructive harvesting and direct determination of one-sided leaf area, collection and weighing of total leaf litterfall), indirect contact methods (allometry, plumb lines, point quadrat methods) and indirect optical methods (Ceptometer, LAI-2000 and hemispherical photographs).

The amount of leaf area in plant canopies influences primary production, transpiration, precipitation interception, microclimate and energy, water and carbon exchanges between vegetation and atmosphere (Pastorella \& Paletto, 2013). Leaf area also influences the amount of diffuse light, which is a good predictor of plant growth (Jarčuška, 2011). Light availability can explain growth; shade-tolerant species can survive long periods in deep shade by greatly reducing their growth in height (Petritan et al., 2008). Growth responses in individual plants are difficult to predict because the factors involved are numerous. The process of natural regeneration may be considered interactive and retroactive. Apart from numerous environmental (external) factors, the natural regeneration is also influenced by internal factors such as genetically-conditioned properties of the species (Jarčuška, 2009).

Biomass allocation ( $R / S$ ratio) is related prevailing to the light conditions and secondarily to other ecological conditions (e.g. soil moisture, nutrient status). According to the optimum allocation theory, trees modify their allocation pattern in order to capture the resource (i.e. light, water, nutrients) that most limits growth (Claveau et al., 2005). Responses to light availability differ according to the species: shade-tolerant species - e.g. European beech - allocate biomass preferentially to the foliage to optimize light capture (Wagner et al., 2010). Generally, these species have a higher R/S ratio than the shade-intolerant species (i.e. Scots pine or European larch).

Starting from these preliminary considerations, the objectives of the paper are: (i) to develop the allometric equations to estimate above-ground and below-ground biomass in Norway spruce and European beech (seedlings and saplings) using total height, (ii) to analyse the influence of the leaf area on ontogenetic growth stages and 
biomass sequestration capacity in the regeneration of these two species.

\section{Materials and methods}

\section{Study sites}

The study was carried out in Trentino province located in the north-east of Italy (Figure 1), which occupies 620,688 ha, of which about $56 \%$ is covered by forests $(345,180$ ha). The main forest types are Norway spruce (Picea abies (L.) H. Karst), European larch (Larix decidua Mill.), European beech (Fagus sylvatica L.) and Scots pine (Pinus sylvestris L.). The Trentino province has a long tradition in the management of public and common forests; nowadays around $76 \%$ of the forest area is managed by the Forest and Wildlife Service of the Trentino province according to forest unit management plans. Furthermore, $18.6 \%$ of the forest area falls within protected areas (Natura 2000 sites, biotopes, natural reserves, national and regional parks).
Trentino province is a mountainous territory $(70.5 \%$ of forests are located above $1,000 \mathrm{~m}$ a.s.l.). The climate is cool, temperate and mild continental with large differences in the temperature and rainfall from valley to valley. The mean annual temperature in the Adige valley is $11.5^{\circ} \mathrm{C}$, while the annual rainfall averages $883 \mathrm{~mm}$ with two main peak periods, in spring (May rainfall averages $94 \mathrm{~mm}$ ) and autumn (October rainfall averages $110 \mathrm{~mm}$ ).

\section{Field data collection}

The samples of Norway spruce and European beech seedlings and saplings were collected in the field during the main growing season (June-October 2012) in 8 study sites distributed in two forest types (Norway spruce forests and European beech forests). The sites were selected by random extraction in Quantum-GIS from the forest types map made by the Forest and Wildlife Service of the Trentino province. From the bioclimatic point of view all sites are included in the "Supratemperate-Wet"

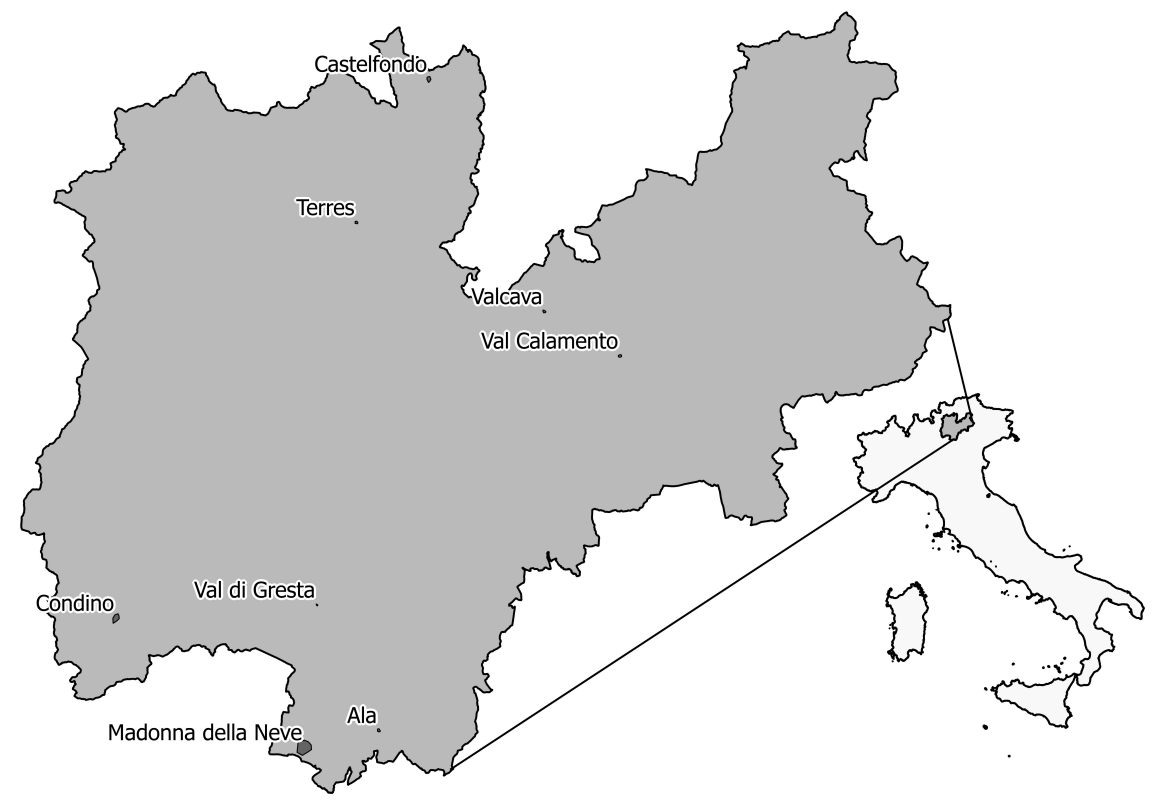

Figure 1. Trentino province (North-East Italy) with highlighted the 8 study sites. 
category of the Rivas-Martinez classification, but there are some differences in average temperature and rainfall.

A set of 47 Norway spruce (22 seedlings and 25 saplings) and 49 European beech (30 seedlings and 19 saplings) samples were collected and measured (Table 1). $60 \%$ of samples were uprooted entirely to estimate above-ground and belowground biomass and to calculate the R/S ratio, while the remaining $40 \%$ of samples were cut at the collar to estimate only the above-ground biomass. These species are selected for two main reasons: their quantitative importance in the Alpine region, and their different responses to light conditions. Norway spruce is a mid-shadetolerant species that dominates the boreal forest zone with Scots pine prevailing on more nutrient-rich, mesic-moist soils, in areas with a more oceanic climate and on sites with a low fire frequency (Barbati et al., 2007). European beech on the other hand is considered to be the most shadetolerant European broad-leaved woody plant (Jarčuška, 2009).

Due to the species distribution in Trentino province, samples were collected from different altitude ranges: Norway spruce from 1,103 to 1,589 $\mathrm{m}$ a.s.l. and European beech between 405 and 1,630 $\mathrm{m}$ a.s.l. In each study site a variable number of samples were collected depending on regeneration density, species composition and site light conditions. The samples were chosen randomly, starting in the centre of the forest management unit and setting a minimum distance between samples of 10 $\mathrm{m}$. The plant height was measured (to the apical bud to the nearest $0.1 \mathrm{~cm}$ ) and a set of hemispherical photographs were used to estimate the Leaf Area Index (LAI) as described below. In the present research, plants less than $30 \mathrm{~cm}$ tall were considered as seedlings, while those with a height between $31 \mathrm{~cm}$ and $130 \mathrm{~cm}$ were considered as saplings.

\section{Plant area index estimation}

In this study, hemispherical photographs were used to estimate the amount of foliage area in a canopy per unit ground surface area (Leaf Area Index - LAI).

For each seedling and sapling sample a set of 16 hemispherical photographs of the canopy - one set of four photographs

Table 1. Distribution of the samples collected by study sites in Trentino province and forest stand characteristics.

\begin{tabular}{lcccccc}
\hline \multirow{2}{*}{ Site name } & $\mathrm{N}$ & $\mathrm{E}$ & $\begin{array}{c}\text { Altitude } \\
(\mathrm{m})\end{array}$ & Forest type & $\begin{array}{c}\text { European } \\
\text { beech }\end{array}$ & $\begin{array}{c}\text { Norway } \\
\text { spruce }\end{array}$ \\
\hline Ala & 657147 & 5067368 & 427 & European beech & 2 & \\
Castelfondo & 663406 & 5148732 & 1,148 & Norway spruce & & 19 \\
Condino & 624308 & 5081384 & 1,315 & European beech & 10 & 3 \\
Madonna della neve & 647795 & 5065225 & 1,608 & European beech & 14 & 3 \\
Terres & 654357 & 5130821 & 1,469 & Norway spruce & 2 & 5 \\
Val Calamento & 687282 & 5114149 & 1,435 & Norway spruce & & 13 \\
Val di Gresta & 649434 & 5083038 & 1,066 & European beech & 15 & 1 \\
Valcava & 677826 & 5119702 & 1,306 & Norway spruce & 6 & 3 \\
\hline
\end{tabular}


per cardinal point following the sequence north, east, west and south - was taken to estimate the LAI. Hemispherical photographs were taken using a Nikon Coolpix 900 camera and a Fish-eye converter Nikon FC-E8 at $1 \mathrm{~m}$ from the ground. The camera was used in the programme mode where exposure time and lens aperture are set automatically using the parameters fixed in FISHEYE1 lens mode (focus set to infinity, widest zoom, metering center-weighted), and the shutter speed was varied automatically by the camera.

Hemispherical photographs were processed by the Spot Light Intercept Model (SLIM) 3.02 following the guidelines given by Pastorella \& Paletto (2013). LAI provided by SLIM software may be considered as "plant area index" or "vegetation area index", because some trunks and tree branches are captured in the images analysed.

\section{Laboratory analysis}

The samples of seedlings and saplings collected in the field were analysed in the laboratory in order to estimate water content and mass. The analyses were carried out within 24 hours after collection in the field to avoid changes in the water content.

Sampled seedlings and saplings were separated at the root collar into aboveground biomass (foliage, stem and branches) and below-ground biomass (stump and roots). The length of roots and shoot was measured with callipers to the nearest 0.1 $\mathrm{cm}$. The sample was then oven-dried for 24 hours at $105{ }^{\circ} \mathrm{C}$ and, after cooling in a dryer with silica gel, reweighed to determine the dry weight. As suggested by the standard "EN 14774-2" (British Standard Institute, 2009), for each collected sample, fresh and dry weight were determined using an electronic analytical balance to the nearest $0.01 \mathrm{~g}$.

\section{Data analysis}

The data are used to calculate for each sapling and seedling sample the following parameters: water content $\left(W_{c}\right)$, dry/fresh weight ratio $\left(\mathrm{R}_{\mathrm{df}}\right)$ for above-ground and below-ground biomass, and root/shoot ratio $(\mathrm{R} / \mathrm{S})$.

The water content, defined as the weight of water in wood expressed as a percentage of the weight of oven-dry wood, was calculated with the following formula:

$W_{c}=\left(\frac{M_{F}-M_{D}}{M_{D}}\right) \cdot 100$

where:

$W_{c}=$ water content as a percentage of oven-dry weight (\%);

$M_{F}=$ fresh (above-ground or belowground) weight (g);

$M_{D}=$ dry (above-ground or below-ground) weight (g).

The dry/fresh weight ratio was calculated with the following formula:

$R_{d f}=\frac{M_{D}}{M_{F}}$

where:

$R_{d f}=$ dry mass $/$ fresh weight ratio $\left(\mathrm{g} \mathrm{g}^{-1}\right)$;

$M_{F}=$ fresh (above-ground or belowground) weight (g);

$M_{D}=$ dry (above-ground or below-ground) weight (g).

The ratio of the below-ground weight to the above-ground weight (R/S ratio) depends on plant form and changes in relation to the light conditions (Cairns et al., 1997; Green et al., 2007). The formula used to calculate $\mathrm{R} / \mathrm{S}$ ratio were the following:

$R / S=\frac{M_{D B g}}{M_{D A g}}$

where:

$R / S=$ dry root/ shoot weight ratio $\left(\mathrm{g} \mathrm{g}^{-1}\right)$;

$M_{D B g}=$ dry root system weight $(\mathrm{g})$;

$M_{D A g}=$ dry stem, branches and foliage

weight (g). 


\section{Statistical analysis}

The data were analysed with $R$ software $(R$ core team, 2013) and two equations were developed in order to estimate Norway spruce and European beech biomass.

Two allometric equations (Eq. 4 and Eq. 5) were used to make estimates using the " $1 \mathrm{~m}$ " function from the "stats" package in $\mathrm{R}$ software. The first estimates biomass from height and the second estimates below-ground (root and stump) biomass from above-ground (stem, branches and foliage) biomass. In our study, scatterplots of the data indicated that the aboveground biomass of seedlings and saplings were non-linearly related to plant height for both species.

The general allometric equation widely accepted is the power equation:

$Y=a X^{b}$

where $Y$ is oven-dry mass $(\mathrm{kg}), X$ is a tree dimension variable (e.g. collar diameter, plant height), $a$ and $b$ are parameters (TerMikaelian \& Korzukhin, 1997).

A second approach uses ordinary least squares estimation after logarithmic transformation of both sides of the power equation (Geudens et al., 2004). Consequently, a non-linear equation by applying logarithms to both sides of the equation is fitted. The regression used is the following:

$\ln \left(M_{D}\right)=a+b(\ln H)$

where:

$M_{D}=$ dry (above-ground or below-ground or total) weight (g);

$H=$ height of the plant $(\mathrm{cm})$;

$a$ and $b=$ equation parameters (intercept and slope of the relationship).

Similarly, scatterplots of the biomass distribution in the different components show that a linear log-log equation better fits the relationship between above-ground biomass and below-ground biomass. Consequently, the following equation was used to estimate the below-ground biomass from the above-ground biomass:

$\ln \left(M_{D B g}\right)=a+b\left(\ln M_{D A g}\right)$

where:

$M_{D B g}=$ dry below-ground biomass of the plants (g);

$M_{D A g}=$ dry above-ground biomass of the plants (g);

$a$ and $b=$ equation parameters (intercept and slope of the relationship).

\section{Results}

\section{Water content}

The water content $\left(\mathrm{W}_{\mathrm{c}}\right)$ of the Norway spruce seedlings is $77.3 \%$ for the shoots and $67.6 \%$ for the roots, while the European beech seedlings have water content of $156.0 \%$ (shoots) and $30.4 \%$ (roots) (Table 2). For the shoot the water content is higher in the European beech, while for the root it is higher in Norway spruce. These results confirm the data of McKay et al. (1999) which show that in seedlings of many species - such as beech and some Picea species - the water content in the root system is inversely proportional to the tree diameter.

Water content of the saplings is lower than that of seedlings for both species: Norway spruce $79.7 \%$ (above-ground component) and $76.9 \%$ (below-ground component), European beech 90.0\% (aboveground component) and $110.3 \%$ (belowground component).

\section{Dry-fresh weight ratio}

Analysis of the Norway spruce aboveground biomass shows a mean dry-fresh weight ratio $\left(\mathrm{R}_{\mathrm{df}}\right)$ equal to 0.56 for the seedlings and 0.56 for the saplings, while for the European beech the mean dry-fresh weight 
Table 2. Mean values of water content (Eq.1), fresh and dry mass (Eq.2) by Norway spruce and European beech seedlings and saplings.

\begin{tabular}{|c|c|c|c|c|c|c|}
\hline & & $\mathrm{N}$ & $M_{F}[g]$ & $M_{D}[g]$ & $W_{c}[\%]$ & $\mathrm{R}_{\mathrm{df}}$ \\
\hline \multicolumn{7}{|c|}{ Norway spruce } \\
\hline \multirow{3}{*}{ Seedlings } & Above-ground & 22 & 43.8 & 24.7 & 77.3 & 0.56 \\
\hline & Below-ground & 18 & 11.4 & 6.8 & 67.6 & 0.60 \\
\hline & Total & 18 & 43.7 & 25.8 & 69.4 & 0.59 \\
\hline \multirow{3}{*}{ Saplings } & Above-ground & 25 & 503.8 & 280.3 & 79.7 & 0.56 \\
\hline & Below-ground & 7 & 49.7 & 28.1 & 76.9 & 0.57 \\
\hline & Total & 7 & 228.4 & 124.7 & 83.2 & 0.55 \\
\hline \multicolumn{7}{|c|}{ European beech } \\
\hline \multirow{3}{*}{ Seedlings } & Above-ground & 30 & 6.4 & 2.5 & 156.0 & 0.39 \\
\hline & Below-ground & 23 & 3.0 & 2.3 & 30.4 & 0.77 \\
\hline & Total & 23 & 8.7 & 5.5 & 58.2 & 0.63 \\
\hline \multirow{3}{*}{ Saplings } & Above-ground & 19 & 51.3 & 27.0 & 90.0 & 0.53 \\
\hline & Below-ground & 14 & 34.7 & 16.5 & 110.3 & 0.48 \\
\hline & Total & 14 & 82.4 & 37.1 & 122.1 & 0.45 \\
\hline
\end{tabular}

ratio is 0.39 for the seedlings and 0.53 for the saplings (Table 2). Similar differences in the mean dry-fresh weight ratio were found for the below-ground biomass: Norway spruce seedlings 0.60 and saplings 0.57 , European beech seedlings 0.77 and saplings 0.48 . Results seem to confirm those of Bolte \& Villanueva (2006) which indicated a space sequestration efficiency and a competitive below-ground ability higher in European beech than in Norway spruce.

\section{$\mathrm{R} / \mathrm{S}$ ratio}

The results show that the R/S ratio is 0.52 for Norway spruce seedlings and 0.27 for saplings, while it is 0.90 for European beech seedlings and 0.76 for saplings. The reduction of the ratio values with tree size (and consequently with age) is in agreement with other studies (Ritson \& Sochacki, 2003; Konôpka et al., 2010). Other authors found $R / S$ ratio values between 1.1 and 1.5 in European beech regeneration (Fotelli et al., 2001; Platt et al., 2004; Curt et al., 2005).

According to Schall et al. (2012) we can observe that the biomass partitioning to shoots and roots in Norway spruce and European beech depends on the ecological characteristics of the species.

\section{Biomass estimation}

Table 3 shows that the sapling or seedling height is a good predictor of aboveground and below-ground biomass, with a $R_{a j}$ value above 0.8 for all equations and a $R_{\text {aj }}^{2}$ value above 0.9 for above-ground biomass of Norway spruce. Schmidt et al. (2009) for the natural regeneration of lenga (Nothofagus pumilio Poepp. \& Endl.) in Chile show $\mathrm{R}_{\text {aj }}$ values between 0.80 and 0.95. In addition, Pajtík et al. (2013) show for the allometric equations for expressing above-ground biomass on the basis of the diameter - a $\mathrm{R}^{2}$ of 0.990 in reference to Norway spruce stem and a $\mathrm{R}^{2}$ of 0.989 for the European beech stem in Slovakia. In the present study, the equation parameters show a high significance level for both species $(p<0.001)$ and the Residual Standard Error (RSE) ranges between 0.66 and 0.77 .

The regression results show that below-ground biomass allocation is strongly related to above-ground biomass. In this study, juvenile Norway spruce has a $\mathrm{R}_{\mathrm{aj}}$. value of 0.96 and juvenile European beech a $\mathrm{R}_{\text {aj }}$ value of 0.95 (Table 4). As shown by Curt et al. (2005) in young plants, these two variables are closely correlated $\left(\mathrm{R}^{2}>0.95\right)$. 
The equation parameters show a high significance level $(p<0.001)$ except for the intercept (a) of the equation for the European beech $(p<0.5)$. Residual Standard Error (RSE) ranges between 0.35 and 0.41 (Tables 3-4).

Some authors have indicated that light and altitude influence plant growth. Ritter et al. (2005) show a dependence of European beech and Norway spruce seedling and sapling growth on light in canopy gaps. In particular, beech seedlings become established under a wide range of canopy openings (Wagner et al., 2010). Cunningham et al. (2006) found that the growth of Norway spruce saplings in Swiss forests is influenced by LAI, tree size and spring snow duration, whereas Kobe \& Hogarth (2007) found that canopy openness may be used to estimate seedling growth.

Mean LAI estimates for Norway spruce were below 3.14 while for European beech they fell below 4.33. This difference agrees with the characteristics of the species, the former being moderately shade tolerant whereas the latter is very shade tolerant. The ANOVA test confirms this difference. The species show a statistical differences in LAI $\left(\mathrm{F}_{1,94}=18.9 ; p<0.001\right)$ suggesting a difference in the biomass allocation strategy.

\section{Discussion}

The main results concerning allometric equations and quantification of the influence of light on young plant growth can be summarized in three points.

First, our study confirms that the light beneath the canopy influences forest regeneration. Young plants may or may not survive under a specific canopy cover (LAI) range. This is usually referred to as shade or light tolerance. The results confirm the ecological characteristics of the two species. Norway spruce is a shadetolerant species that can exist as advanced regeneration beneath the canopy of a mature forest stand (Lundqvist \& Fridman,

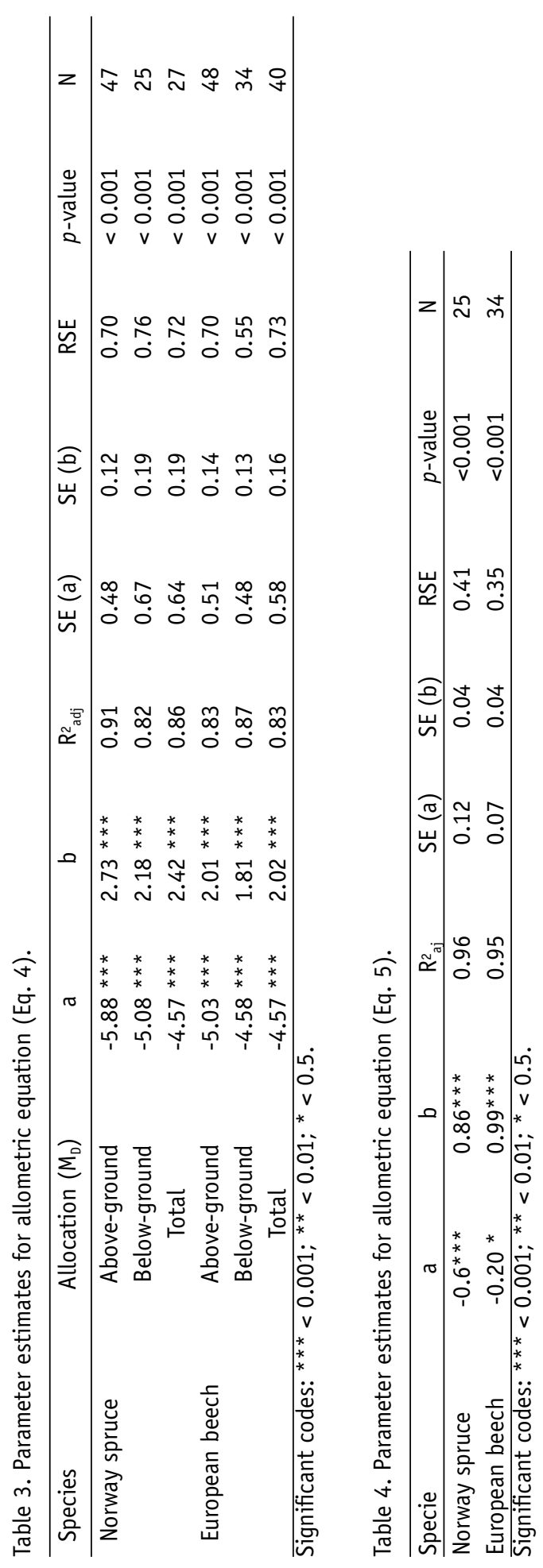




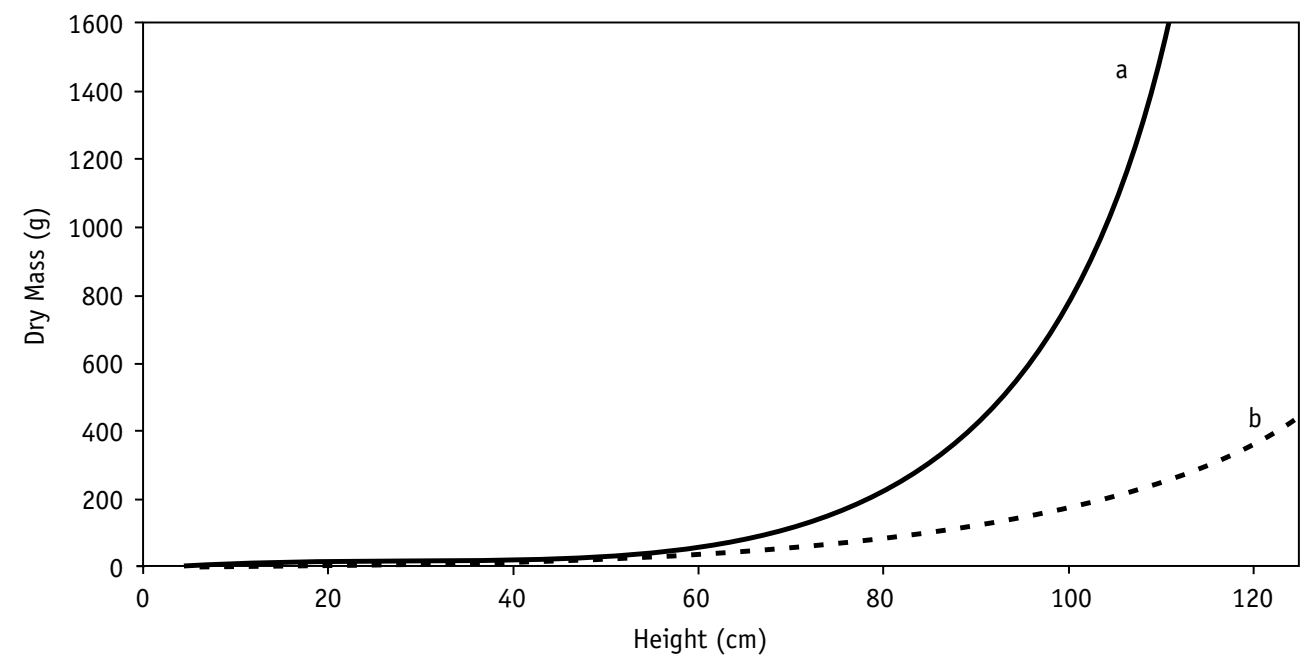

Figure 2. Comparison of height and above-ground biomass equations for Norway spruce: $a$ - our study; $b$ Mitt et al. (2014).

1996), whereas European beech is a very shade-tolerant species (Götmark et al., 2005). Madsen \& Larsen (1997) found unsuccessful regeneration beneath canopies with LAI above 3.5. Seedlings and saplings of European beech become established under a wide range of canopy cover. Generally, seedlings of beech grow more slowly than most associated species (i.e. ashes and maples), and they survive better at low or intermediate light (Wagner et al., 2010). Small forest gaps may provide favourable conditions for photosynthesis and growth of beech regeneration as a result of the limited ability of seedlings to acclimate to sudden increases in high irradiance (Tognetti et al., 1998). Beech seedlings survive for long periods at very low light levels (Relative Light Intensity, RLI $=1 \%$ ), but they grow slowly. Height and diameter growth are best in the open (RLI $=100 \%$ ), but almost as good with light at 30\% < RLI < 50\% (Wagner et al., 2010). Such seedlings may experience virtually no height growth for several years, but they can resume rapid growth by the creation of a gap in the canopy (Price et al., 2001).
Second, biomass allocation shows differences related to the species characteristics and to the plant age. In particular, both biomass allocation and water content depend on species and age class. European beech shows a lower biomass accumulation rate than Norway spruce. Besides, the comparison between the allometric equation developed in this study and the one developed by Mitt et al. (2014) in Estonia highlights that probably the geographical latitude affects the relationship between biomass and height (Figure 2). The comparison shows that at about $50 \mathrm{~cm}$ height saplings growth faster in the Alps.

Third, seedling and sapling biomass allocation may be estimated from height, while below-ground biomass may be estimated from above-ground biomass with high precision. These relationships have often been analysed for adult trees, but rarely in young ones. Both the equations confirmed the results of previous studies: the first gives $\mathrm{R}^{2}$ aj values between 0.8 and 0.91 , while the second gives $\mathrm{R}_{\text {aj }}$ values above 0.95 . 


\section{Conclusions}

The study focuses on the analysis of the biomass allocation in the regeneration of European beech and Norway spruce in the Italian Alps. Biomass allocation in young trees at different stages of development is important information to study the response of species (shade-tolerant, midshade-tolerant, shade-intolerant) to site conditions (such as light). Generally, plant biomass estimation requires destructive methods, but the development of a robust non-destructive method of estimation using simple measurable variables would provide a useful tool for forest managers. Besides, the method should be useful to estimate the carbon sequestration rate in young forests and to forecast the biomass in forest gaps jointly with remote sensing methods.

The equations developed in this study are site-specific, their application should be restricted to site conditions similar to the basis of this study. Further analysis for validate and verify the presented models with new data from a wider range of site are recommended.

Acknowledgments. This work was supported by the Foundation of the "Cassa di Risparmio di Trento e Rovereto" (Grants for young researchers - 2011).

\section{References}

Barbati, A., Corona, P.M., Marchetti, M. 2007. European forest types. Categories and types for sustainable forest management reporting and policy. - European Environment Agency, Copenhagen.

Blujdea, V.N.B., Pilli, R., Dutca, I., Ciuvat, L., Abrudan, I.V. 2012. Allometric biomass equations for young broadleaved trees in plantations in Romania. Forest Ecology and Management, 264, 172-184.

Bolte, A., Villanueva, I. 2006. Interspecific competition impacts on the morphology and distribution of fine roots in European beech (Fagus sylvatica L.) and Norway spruce (Picea abies (L.) Karst.). European Journal of Forest Research, 125, 15-26.
British Standard Institute 2009. BS EN 14774-2:2009: Solid biofuels - Determination of moisture content - oven dry method. Part 2: Total moisture simplified method. BS EN 14774-2:20092009.

Cairns, M.A., Brown, S., Helmer, E.H., Baumgardner, G.A. 1997. Root biomass allocation in the world's upland forests. - Oecologia, 111, 1-11.

Canham, C.D., Marks, P.L. 1985. The response of woody plants to disturbance: patterns of establishment and growth. - Pickett T.A., White P.S. (eds). The ecology of natural disturbance and patch dynamics. Academic Press, Orlando, 119-217.

Cienciala, E., Černý, M., Apltauer, J., Exnerová, Z. 2005. Biomass functions applicable to European beech. - Journal of Forest Science, 51, 147-154.

Claesson, S., Sahlén, K., Lundmark, T., 2001. Functions for biomass estimation of young Pinus sylvestris, Picea abies and Betula spp. From stands in Northern Sweden with high stand densities. Scandinavian Journal of Forest Research, 16, 138-146.

Claveau, Y., Messier, C., Comeau, P.G. 2005. Interacting influence of light and size on aboveground biomass distribution in sub-boreal conifer with contrasting shade tolerance. - Tree Physiology, $25,373-384$

Cunningham, C., Zimmermann, N.E., Stoeckli, V., Bugmann, H. 2006. Growth of Norway spruce (Picea abies L.) saplings in subalpine forests in Switzerland: Does spring climate matter? - Forest Ecology and Management, 228, 19-32.

Curt, T., Coll, L., Prevosto, B., Balandier, P., Kunstler, G. 2005. Plasticity in growth, biomass allocation and root morphology in beech seedlings as induced by irradiance and herbaceous competition. - Annals of Forest Science, 62, 51-60.

DeLucia, E.H., Sipe, T.W., Herrick, J., Maherali, H. 1998. Sapling biomass allocation and growth in the understory of a deciduous hardwood forest. American Journal of Botany, 85, 955-963.

Durkaya, B., Durkaya, A., Makineci, E., Ülküdür, M. 2013. Estimation of above-ground biomass and sequestered carbon of Taurus Cedar (Cedrus libani L.) in Antalya, Turkey. - iForest - Biogeosciences and Forestry, 6, 278-284.

Elliott, K.J., Clinton, B.D. 1993. Equations for estimating biomass of herbaceous and woody vegetation in early-successional Southern Appalachian pine-hardwood forests. - Research Note SE-365, Forest Service, U.S.D.A. United States Department of Agriculture.

Fotelli, M.N., Gessler, A., Peuke, A.D., Rennenberg, H. 2001. Drought affects the competitive interactions between Fagus sylvatica seedlings and an early successional species, Rubus fruticosus: responses of growth, water status and delta13C composition. - New Phytologist, 151, 427-435.

Geudens, G., Staelens, J., Kint, V., Goris, R., Lust, N. 2004. Allometric biomass equations for Scots pine (Pinus sylvestris L.) seedlings during the first years 
of establishment in dense natural regeneration. Annals of Forest Science, 61, 653-659.

Götmark, F., Fridman, J., Kempe, G., Norden, B. 2005. Broadleaved tree species in conifer-dominated forestry: Regeneration and limitation of saplings in southern Sweden. - Forest Ecology and Management, 214, 142-157.

Green, C., Tobin, B., O'Shea, M., Farrell, E.P., Byrne, K.A. 2007. Above- and belowground biomass measurements in an unthinned stand of Sitka spruce (Picea sitchenisis (Bong) Carr.). - European Journal of Forest Research, 126, 179-188.

Jarčuška, B. 2009. Growth, survival, density, biomass partitioning and morphological adaptations of natural regeneration in Fagus sylvatica. A review. - Dendrobiology, 61, 3-11.

Jarčuška, B. 2011. Morphological plasticity of leaves in natural regeneration of Fagus sylvatica L.: effects of direct and diffuse light, ontogeny and shoot type. - Polish Journal of Ecology, 89, 339-353.

Jonckheere, I., Muys, B., Coppin, P. 2005. Allometry and evaluation of in situ optical LAI determination in Scots pine: a case study in Belgium. - Tree Physiology, 25, 723-732.

Kobe, R.K., Hogarth, L.J. 2007. Evaluation of irradiance metrics with respect to predicting sapling growth. - Canadian Journal of Forest Research, 37, 1203-1213.

Konôpka, B., Pajtík, J., Moravčík, M., Lukac, M. 2010. Biomass partitioning and growth efficiency in four naturally regenerated forest tree species. Basic and Applied Ecology, 11, 234-243.

Levy, P.E., Hale, S.E., Nicoll, B.C. 2004. Biomass expansion factors and root: shoot ratios for coniferous tree species in Great Britain. - Forestry, 77, 421-430.

Liang, S., Li, X., Wang, J. 2012. Advanced Remote Sensing: Terrestrial Information Extraction and Applications. Amsterdam, Academic Press. 799 p.

Lundqvist, L., Fridman, E. 1996. Influence of local stand basal area on density and growth of regeneration in uneven-aged Picea abies stands. Scandinavian Journal of Forest Research, 11, 364-369.

Madsen, P., Larsen, J.B. 1997. Natural regeneration of beech (Fagus sylvatica L.) with respect to canopy density, soil moisture and soil carbon content. Forest Ecology and Management, 97, 95-105.

McKay, H.M., Jinks, R.L., McEvoy, C. 1999. The effect of desiccation and rough-handling on the survival and early growth of ash, beech, birch and oak seedlings. - Annals of Forest Science, 56, 391-402.

Mitt, R., Padari, A., Samsonov, M. 2014. Modelling of woody biomass on electricity pylons. - Forestry Studies / Metsanduslikud Uurimused, 60, 44-56.

Øyen, B,-H., Nilsen, P., Bøhler, F., Andreassen, K. 2011. Predicting individual tree and stand diameter increment responses of Norway spruce (Picea abies (L.) Karst.) after mountain forest selective cutting. - Forestry Studies / Metsanduslikud Uurimused, 55, 33-45.

Pajtík, J., Konôpka, B., Lukac, M. 2011. Individual biomass factors for beech, oak and pine in Slovakia: A comparative study in young naturally regenerated stands. - Trees - Structure and Function, 25, 277-288.

Pajtík, J., Konôpka, B., Marušák, R. 2013. Aboveground net primary productivity in young stands of beech and spruce. - Forestry Journal, 59, 154162.

Pastorella, F., Paletto, A. 2013. A comparative analysis of image processing softwares to indirect estimation of leaf area index in forest ecosystems. Folia Oecologica, 40, 225-236.

Penman, J., Gytarsky, M., Hiraishi, T., Krug, T., Kruger, T., Pipatti, D., Buendia, L., Miwa, K., Ngara, T., Tanabe, T., Wagner, F. (eds). 2004. IPCC good practice guidance for land use, land use change and forestry. Institute for Global Environmental Strategies (IGES). Hayama, Kanagawa, Japan.

Petrițan, A.M., Lüpke, B., Petrițan, I.C. 2008. Influence of light availability on growth, leaf morphology and plant architecture of beech (Fagus sylvatica L.), maple (Acer pseudoplatanus L.) and ash (Fraxinus excelsior L.) saplings. - European Journal of Forest Research, 128, 61-74.

Platt, K.H., Allen, R.B., Coomes, D.A., Wiser, S.K. 2004 Mountain beech seedling responses to removal of below-ground competition and fertiliser addition. - New Zealand Journal of Ecology, 28, 289293.

Price, D.T., Zimmermann, N.E., Van Der Meer, P.J., Lexer, M.J., Leadley, P., Jorritsma, I.T.M., Clark, D.F., Lasch, P., Mcnulty, S., Wu, J., Smith, B. 2001. Regeneration in gap models: priority issues for studying forest responses to climate change. Global Environmental Change, 51, 475-508.

R Core Team 2013. R: A language and environment for statistical computing. $\mathrm{R}$ Foundation for Statistical Computing. Vienna, Austria. [WWW Document]. - URL http://www.R-project.org/ [Accessed 30 November 2014].

Ritson, P., Sochacki, S. 2003. Measurement and prediction of biomass and carbon content of Pinus pinaster trees in farm forestry plantations, south-western Australia. - Forest Ecology and Management, 175, 103-117.

Ritter, E., Dalsgaard, L., Einhorn, K.S. 2005. Light, temperature and soil moisture regimes following gap formation in a semi-natural beech-dominated forest in Denmark. - Forest Ecology and Management, 206, 15-33.

Ruiz-Peinado, G.R., Montero, G., del Rio, M. 2012. Biomass models to estimate carbon stocks for hardwood tree species. - Forest Systems, 21, 42-52.

Schall, P., Lödige, C., Beck, M., Ammer, C. 2012. Biomass allocation to roots and shoots is more sensitive to shade and drought in European 
beech than in Norway spruce seedlings. - Forest Ecology and Management, 266, 246-253.

Schmidt, A., Poulain, M., Klein, D., Krause, K., Peña-Rojas, K., Schmidt, H., Schulte, A. 2009. Allometric above-belowground biomass equations for Nothofagus pumilio (Poepp. \& Endl.) natural regeneration in the Chilean Patagonia. Annals of Forest Science, 66, 513-520.

Skovsgaard, J.P., Nord-Larsen, T. 2012. Biomass, basic density and biomass expansion factor functions for European beech (Fagus sylvatica L.) in Denmark. - European Journal of Forest Research, 131, 1035-1053.

Teobaldelli, M., Somogyi, Z., Migliavacca, M., Usoltsev, V.A. 2009. Generalized functions of biomass expansion factors for conifers and broadleaved by stand age, growing stock and site index. - Forest Ecology and Management, 257, 1004-1013.

Ter-Mikaelian, M.T., Korzukhin, M. 1997. Biomass estimations for 65 North American tree species. Forest Ecology and Management, 97, 1-24.

Ter-Mikaelian, M.T., Parker, W.C. 2000. Estimating biomass of white spruce seedlings with vertical photo imagery. - New Forest, 20, 145-162.

Tognetti, R., Minotta, G., Pinzauti, S., Michelozzi, M., Borghetti, M. 1998. Acclimation to changing light conditions of long-term shade-grown beech (Fagus sylvatica L.) seedlings of different geographic origins. - Trees, 12, 326-333.

UNFCCC. 1992. United Nations Framework Convention on Climate Change. FCCC/INFORMAL/ 84. Retrieved February 2010. [WWW Document]. URL www.unfccc.int/resource/docs/convkp/ conveng.pdfl. [Accessed 30 November 2014].

UNFCCC. 1997. Kyoto Protocol to the Framework Convention on Climate Change. [WWW Document]. - URL http://unfccc.int/resource/docs/ convkp/kpeng.pdf. [Accessed 30 November 2014].

Wagner, S., Collet, C., Madsen, P., Nakashizuka, T., Nyland, R.D., Sagheb-Talebi, K. 2010. Beech regeneration research: From ecological to silvicultural aspects. - Forest Ecology and Management, 259, 2172-2182.

Watson, D.J. 1947. Comparative physiological studies in growth of field crops. I. Variation in net assimilation rate and leaf area between species and varieties, and within and between years. - Annals of Botany, 11, 41-76. 